\title{
Monitoring drug resistance in Plasmodium falciparum clinical isolates collected from Northern Thailand
}

\author{
Chairat Uthaipibull ${ }^{1 *}$, Patcharaporn Saengratwatchara² ${ }^{2}$ Manon Boonbangyang ${ }^{1}$, Parichat Prommana', \\ Sumalee Kamchonwongpaisan ${ }^{1}$, Somdet Srichiratanakool ${ }^{2}$
}

From Challanges in malaria research: Core science and innovation

Oxford, UK. 22-24 September 2014

\section{Background}

Drug resistance developed by $P$. falciparum is a real threat to malaria disease control and treatment. Recent reports from the Thai-Cambodia and Thai-Myanmar borders have described the artemisinin resistance developed by the parasite. Therefore, there is a need to monitor emergence of resistance parasites in order to limit their spread.

\section{Materials and methods}

Clinical isolates were collected from patients infected with $P$. falciparum. The parasites were adapted in in vitro culture and tested for $50 \%$ inhibitory concentration $\left(\mathrm{IC}_{50}\right)$ against pyrimethamine (Pyr), chloroquine (CQ), mefloquine (MQ) and dihydroartemisinin (DHA) using standard malaria SYBR Green I-based fluorescence (MSF) assay. Mutations of genes associated with drug resistance were also investigated.

\section{Results and conclusions}

All the tested clinical isolates were resistant to Pyr and $C Q$, even though Pyr was not used in the area for a long time, while CQ is still used to treat $P$. vivax infection. Only some of the isolates were resistant to MQ, while all of them were sensitive to DHA using standard drug sensitivity assay. Pyr- and CQ-resistant isolates contained mutations at dihydrofolate reductase (Pfdhfr) and chloroquine resistance transporter $(P f c r t)$ genes as expected. The results confirm the existence of drug resistance parasites and suggest the use of proper drugs for malaria treatment in the field.

\footnotetext{
${ }^{1}$ National Center for Genetic Engineering and Biotechnology (BIOTEC), National Science and Technology Development Agency (NSTDA), Pathum Thani, Thailand

Full list of author information is available at the end of the article
}

\section{Acknowledgements}

The work was supported by the Thailand Graduate Institute of Science and Technology (TGIST) and Cluster and Program Management Office, National Science and Technology Development Agency (NSTDA).

\section{Authors' details}

${ }^{1}$ National Center for Genetic Engineering and Biotechnology (BIOTEC), National Science and Technology Development Agency (NSTDA), Pathum Thani, Thailand. ${ }^{2}$ Department of Biochemistry, Faculty of Medicine, Chiang Mai University, Chiang Mai, Thailand.

Published: 22 September 2014

doi:10.1186/1475-2875-13-S1-P89

Cite this article as: Uthaipibull et al:: Monitoring drug resistance in Plasmodium falciparum clinical isolates collected from Northern Thailand. Malaria Journal 2014 13(Suppl 1):P89.
Submit your next manuscript to BioMed Central and take full advantage of:

- Convenient online submission

- Thorough peer review

- No space constraints or color figure charges

- Immediate publication on acceptance

- Inclusion in PubMed, CAS, Scopus and Google Scholar

- Research which is freely available for redistribution

Submit your manuscript at www.biomedcentral.com/submit
() Biomed Central 